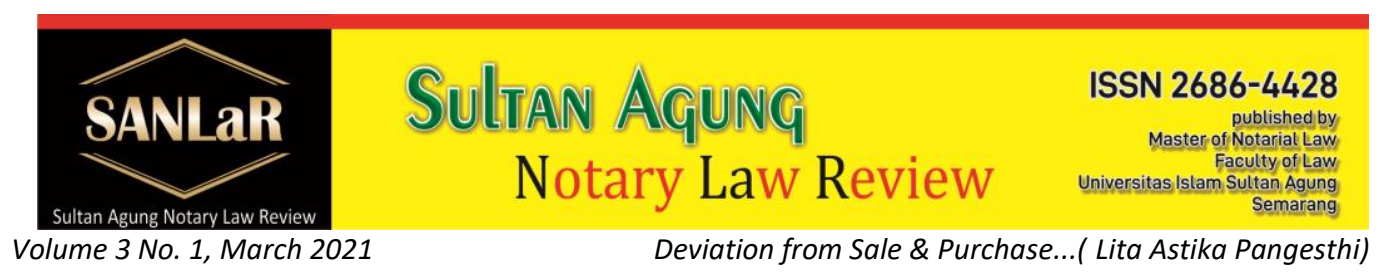

\title{
Deviation from Sale \& Purchase Agreement Made by A Notary in Sale of Land
}

\author{
Lita Astika Pangesthi ${ }^{*}$ and Amin Purnawan ${ }^{* *}$ \\ ${ }^{*}$ ) Student of Master of Notary Law, Faculty of Law, Universitas Islam Sultan \\ Agung Semarang, E-mail: litaastikapangesthi@gmail.com \\ * *) Lecturer Master of Notary Law, Faculty of Law, Universitas Islam Sultan Agung \\ Semarang
}

\begin{abstract}
A sale and purchase agreement is an agreement between the seller and the buyer, prior to the execution of the Sale and Purchase Deed. Because there are requirements in the sale and purchase that have not been fulfilled, these requirements include: a certificate of land title is in process, the price has not been paid for the sale and purchase of the land, or because the taxes imposed have not been able to be paid by the seller or the buyer. The purpose of this research is to examine: 1). Implementation of PPJB made by a Notary in buying and selling land, 2). Irregularities and solutions in the implementation of PPJB made by Notaries in the sale and purchase of land. The approach method in this research is Normative Juridical. Legal research is carried out by examining library materials or secondary data as the basic material for research by conducting a search of the regulations and literatures related to the problem under study. ${ }^{1}$ Conclusion with the making of the Sale and Purchase Agreement by the Notary Public, in its implementation, legal deviations are not uncommon, among others: 1). PPJB is not always behind the name of the buyer, but is resold to a third party, 2). Transaction value in $A J B$ is not in accordance with PPJB, 3). Authorization to sell for PPJB paid off separately.
\end{abstract}

Keywords: Sale and Purchase Binding Agreement; Sale and Purchase; Deviation.

\section{Introduction}

The community's need for land in life is very important. Because land is multidimensional, seen from an economic, political, cultural perspective and can also mean something sacred. This makes people compete to control and own the land they want, therefore making land something that has a selling value. Buying

\footnotetext{
1 Mamudji, Soerjono Soekanto and Sri. (2001). Penelitian Hukum Normatif (Suatu Tinjauan Singkat), Jakarta: Rajawali Pers. p.13-14.
} 
and selling land for the community is no longer a new thing, since the old days, land buying and selling has existed. Unlike in the past, the community only used receipts as proof of payment in land sale and purchase transactions, but nowadays people prefer to enter into or make agreements in the practice of buying and selling land.

Because this agreement is considered stronger than just a receipt. This agreement is known as a Sale and Purchase Agreement or a Sale and Purchase Agreement. This Sale and Purchase Agreement (PPJB) can be made in the form of an underhand agreement or it can also be made in the form of an authentic deed. An agreement under the hand is an agreement made by the parties themselves which is witnessed by the closest people or people already known by the parties. Whereas an agreement made in the form of an authentic deed is a deed of agreement made before a notary (deed partij), which is a deed that contains a description of what is explained or told by the parties who have presented to the notary, for example, credit agreements, sale and purchase and so on. ${ }^{2}$ This sale and purchase agreement depends on the agreement of the parties, to be made in the form of an underhand agreement or made before a notary in the form of an authentic deed.

The Sale and Purchase Agreement (PPJB) usually occurs because the parties cannot immediately conduct a sale and purchase which is followed up with a Sale and Purchase Deed (AJB). This is because there are several factors and conditions that have not been met, such as:

1) Payment for sale and purchase of land that has been agreed upon has not yet been paid;

2) The certificate of land rights which is the object of sale and purchase is still in process;

3) Letters or documents that become administrative requirements are not complete;

4) The tax imposed on the sale and purchase of land rights has not been paid by the seller or the buyer.

Or other possibilities that cause this Sale and Purchase Agreement to be selected by the parties in the sale and purchase of land.

Although in practice the PPJB is often used in the sale and purchase of land, in fact the Sale and Purchase Agreement (PPJB) has never been explicitly regulated in the laws and regulations relating to land rights, because the PPJB is an agreement born out of necessity, so the binding agreement buying and selling

\footnotetext{
${ }^{2}$ Herman, Benny. Akta Notaris, (Jakarta : www. Hukumonline ed.19 February 2010), main page.
} 
does not have a certain form. This is also in accordance with the opinion of Herlien Budiono, ${ }^{3}$ sale and purchase agreement agreement is an assistance agreement that functions as a preliminary agreement which is free form. So that in the implementation of the sale and purchase of land using a sale and purchase agreement, legal deviations sometimes occur.

Therefore, from the description above, it becomes my background for discussing deviations from the sale and purchase agreement made by a notary in the sale and purchase of land.

\section{Research Methods}

The research method used in this paper is normative juridical. The research was conducted based on legal materials which focused on library data and secondary data. According to Soerjono Soekanto, normative juridical research is legal research which is carried out by examining library materials or secondary data as the basic material to be researched by conducting a search on regulations and literature related to the problem under study. ${ }^{4}$ The approach used is a statutory approach (statute approach) and a conceptual approach (conceptual approach). Where legal materials are obtained from library materials, including legal books, journals or research results, literature, statutory regulations, notary deeds, and other sources.

\section{Results and Discussion}

\subsection{Implementation of PPJB Made by Notary in the Sale and Purchase of Land}

The Sale and Purchase Agreement (PPJB) is the first step before being followed up with a Sale and Purchase Deed (AJB). This PPJB is a form of agreement between the two parties that bind themselves to one another regarding the fulfillment of the rights and obligations of both parties for the sale and purchase of land according to what is stated in the agreement.

According to R. Subekti ${ }^{5}$, PPJB is an agreement between the seller and the buyer before the sale and purchase is carried out due to the elements that must be fulfilled for the sale and purchase, among others, the certificate of land rights does not exist because there is still a process, or the price or taxes imposed have not been paid the sale and purchase of land rights has not been paid by either the seller or the buyer.

There are two forms of Sale and Purchase Agreement (PPJB), namely PPJB not paid off and PPJB paid off. PPJB is not paid in full, which in this case means an

\footnotetext{
${ }^{3}$ Budiono, Herlien. Artikel "Pengikat Jual Beli Dan Kuasa Mutlak" Majalah Renvoi, ed. I, No 10, March 2004, p. 57.

${ }^{4}$ lbid.

${ }^{5}$ R.Subekti. (1987). Hukum Perjanjian, Bandung : Bina Cipta. p.75.
} 
agreement made if the price has not been paid in the sale and purchase of land, while PPJB is paid off is an agreement made when the sale and purchase price of land has been paid but there are administrative requirements that have not been fulfilled or maybe a certificate of right process over unfinished land. PPJB is paid off in the making, usually followed by the creation of a Selling Authority. The function of this Proxy to sell is so that in the future when following up the PPJB with the Sale and Purchase Deed, when a signing is needed from the seller, the seller does not need to be brought back.

Regarding the form of the sale and purchase agreement made by a Notary, it must follow as stipulated in Act No. 2 of 2014 concerning Amendments to Act No. 30 of 2004, which is stated in Article 38 of the UUJN regarding the form and nature of the deed, it is stated:

(1) Each Deed consists of:

a.The beginning of the Deed or the head of the Deed;

b. Deed bodies; and

c. End or closing of the Deed.

(2) The beginning of the Deed or the head of the Deed contains:

a.title Deed;

b. deed number;

c. hour, day, date, month and year; and

d. full name and domicile of the Notary.

(3) The Deed Body contains:

a. full name, place and date of birth, nationality, occupation, position, position, residence of the actors and / or the person they represent;

b. information regarding the position of acting against;

c. the contents of the Deed which constitute the will and desire of the interested parties; and

d. the full name, place and date of birth, as well as occupation, position, position and place of residence of each identifying witness.

(4) The end or closing of the Deed contains:

a. a description of the reading of the Deed as referred to in Article 16 paragraph (1) eye letter Article 16 paragraph (7); 
b. a description of the signing and place of signing or translation of the Deed, if any;

c. full name, place and date of birth, occupation, position, position, and the place of residence of each witness to the Deed; and

d. a series regarding the absence of changes that have occurred in the making of Deeds or a description of the changes which may be in the form of additions, deletions, or replacements as well as the number of changes.

PPJB was created, ownership of land rights has not been transferred from the prospective seller to the prospective buyer even though the entire price has been fully paid by the prospective buyer. The intention of these parties is that the object of sale and purchase in the form of land rights in the PPJB cannot be tied or agreed to be transferred to another party by the owner.

Based on the position of the Sale and Purchase Agreement, it must be followed up with the making of a Sale and Purchase Deed when transferring land rights. Referring to Article 37 paragraph (1) of Government Regulation No. 24 of 1997 concerning Land Registration, after the fulfillment of the conditions referred to in the PPJB and the power to sell, it must be followed up with the creation of an $A J B$ and then immediately re-register the name at the Land Office. Because legally, the rights to the land have only been transferred to the prospective buyer after changing the name to the name of the potential buyer.

The sale and purchase deed is a deed which is used as one of the requirements to prove that there has been a transfer of land rights. The authority in making deed of transfer of land rights is described in article 1 paragraph 1 of Government Regulation Number 24 of 1997 concerning the Position of Land Deed Making Officials, that Land Deed Making Officials, hereinafter referred to as PPAT, are public officials who are given the authority to make authentic deeds regarding certain legal actions regarding land rights or property rights over apartment units.

In connection with the Sale and Purchase Agreement made by notary, Article 1870 of the Civil Code has affirmed that deeds made before a Notary have perfect evidentiary power, based on Article 1870 of the Civil Code "An authentic deed provides between the parties and their heirs or people who get rights from them, a perfect proof of what is contained in it."

The power of proof of notarial deeds is a direct result of statutory provisions, that there must be an authentic deed as proof of the duties imposed by law on 
certain officials or people. It is in this assignment that lies a sign of trust in these officials and the granting of evidentiary power to the deeds they make. ${ }^{6}$

\subsection{Irregularities and Solutions in the Implementation of PPJB Made by Notaries in the Sale and Purchase of Land}

Considering the position of PPJB which is only an initial agreement in the sale and purchase of land, and in its implementation, buyers often do not immediately follow up again with the making of AJB even though all the requirements are met, then in its implementation sometimes legal irregularities occur. The legal deviations include:

1) The sale and purchase agreement made between the prospective seller and the buyer is not always reversed on behalf of the prospective buyer listed in the PPJB, but is resold to a third party. In this case there are two possibilities; a). The prospective seller intends to sell again with a third party, or b). Prospective Buyers who intend to sell the land again to a third party. If this happens, then for the possibility (a) the prospective seller wants to sell his land again to a third party, the PPJB that has been previously made must be canceled first, and the prospective seller must return the money that has been given by the prospective buyer to the prospective seller as payment for the price sale of land that has been fully agreed upon, because with the PPJB, the two parties are bound to each other, and there are respective obligations that must be fulfilled. The existence of this PPJB is also proof that the prospective seller has binded himself to the prospective buyer, that the land that was promised in the PPJB cannot be promised or tied again to a third party. If the prospective seller continues to sell the land to a third party, then in this case a legal violation occurs, and the PPJB can be canceled or the prospective buyer can file a lawsuit as a legal remedy. As for the possibility (b) of the prospective buyer who intends to sell the land to a third party again, if the PPJB is an PPJB not paid off (installments), then the obligations of the prospective buyer must be settled first, such as: the selling price of the object of sale (land ) must be paid in full first, Then it is followed up with the making of the Sale and Purchase Deed, as well as the PPJB is paid off after the administrative requirements are met, then the PPJB must also be followed up again by making the Sale and Purchase Deed. If all the obligations of the prospective buyer have been carried out and the PPJB has been followed up with the creation of the $A J B$, then the transfer of land rights can be carried out. After the land has transferred ownership of the land title (behind the name) from the prospective seller to the prospective buyer, then the land can be sold again to a third party. However, if both parties are still bound by an PPJB, then the prospective buyer resells the land to a

${ }^{6}$ Tobing, G.H.S. Lumban. (1992). Peraturan Jabatan Notaris, Jakarta : Erlangga. p. 214. 
third party, then in this case legal irregularities occur, because there are obligations and procedures that are not carried out.

2) The existence of tax evasion / loss, because it avoids the amount of tax value imposed on the object of sale and purchase of land, sometimes the transaction value stated in the Sale and Purchase Deed does not match the real price or the price of the object for sale and purchase of land as agreed in the Sale and Purchase Agreement.

3) The power to sell that is given by the prospective seller to the prospective buyer is usually irrevocable, where the power of attorney applies if all the conditions agreed upon in the PPJB set by the prospective seller have been met by the prospective buyer. This situation is then called by many people as absolute power because this power cannot be revoked. The use of absolute power itself is a means of transferring rights to land, nothing but a hidden way because many parties use and use absolute power as a means of exercising control over land rights even though legally they do not have the right to own it.

To avoid legal deviations that occur in the implementation of the Sale and Purchase Agreement as a legal remedy, then the things that must be considered in the preparation and implementation of the Sale and Purchase Agreement are as follows:

a. Data on the object of sale and purchase (land or land along with buildings) must be absolutely clear, which is written in the certificate of land with those in the location, it is clear who the holder is;

b. The price of the object for sale and purchase of land and how it is paid, whether in stages (installments) or in full;

c. Include clauses of certain cancellation conditions, for example: if one of the parties has bad faith, or one of the parties is in default, then a cancellation can be made of the Sale and Purchase Agreement that has been made;

d. Confirmation regarding the payment of taxes and other fees which are the obligations of each party;

e. Inserting or adding a clause to the statement, that the prospective seller guarantees the land being sold is not under debt collateral and is involved in a dispute, if the statement of the prospective seller is not true, then the prospective seller must be willing to release the prospective buyer from all claims of any party. 
Actually, the Sale and Purchase Agreement Agreement is an agreement as in general, which is an act in which one or more people bind themselves to one or more other people (article 1313 of the Civil Code). PPJB was born as a result of the open nature of Book III of the Civil Code, article 1338, which gives legal subjects the widest possible freedom to enter into agreements that contain anything as long as they do not conflict with law, order, and norms of decency. The validity of an agreement either made under the hand or an authentic deed if it meets the requirements contained in Article 1320 of the Civil Code, namely an agreement for those who bind themselves, are competent to make an engagement, a certain thing, and a lawful cause.

\section{Closing}

\subsection{Conclusion}

1. PPJB is a preliminary agreement in the implementation of land sale and purchase. PPJB is a form of agreement between the two parties that bind themselves to one another, regarding the fulfillment of the rights and obligations of both parties for the sale and purchase of land according to what is stated in the agreement. PPJB occurs because several factors and conditions have not been met, such as:

a. Payment for sale and purchase of land that has been agreed upon has not yet been paid;

b. The certificate of land rights which is the object of sale and purchase is still in process;

c. Letters or documents that become administrative requirements are not complete;

d. The tax imposed on the sale and purchase of land rights has not been paid by the seller or the buyer.

There are two forms of Sale and Purchase Agreement (PPJB), namely PPJB not paid off and PPJB paid off.

2. In accordance with the position of the PPJB which is the initial agreement in the sale and purchase of land, in its implementation of the PPJB sometimes legal irregularities occur, such as:

a) PPJB is not always reversed on behalf of the buyer listed in the PPJB, but is resold to a third party;

b) Tax evasion / loss, kbecause the transaction value does not match the real price; 
C) Power to sell is often used separately and is not an integral part of the PPJB.

\subsection{Suggestion}

1. The notary, in making the Sale and Purchase Agreement, should include clear and complete confirmation clauses regarding certain cancellation conditions, for example if one of the parties has bad faith, or one of the parties is in default, the agreement can be canceled, so that it can provide legal protection for prospective sellers and potential buyers.

2. For the public, it is recommended that in using the Sale and Purchase Agreement, in its implementation, pay attention to and fulfill the obligations that have been charged, and not use PPJB as an effort to avoid taxes because it can harm the state.

3. For the government, it should be able to provide clearer arrangements regarding the Sale and Purchase Agreement in positive law in Indonesia.

\section{References}

Books:

[1] Ahmadi Miru and Sakka Pati. (2012). Hukum Perikatan. Jakarta: Rajawali Pers.

[2] Habib Adjie. (2008). Hukum Notaris Indonesia. Bandung: PT. Refika Aditama.

[3] Herlien Budiono. Artikel Pengikat Jual Beli Dan Kuasa Mutlak Majalah Renvoi, edisi tahun I, No 10, Bulan March 2004

[4] ....................... (2011). Ajaran Umum Hukum Perjanjian dan Penerapannya di bidang Kenotariatan. Bandung: Citra Aditya Bakti.

[5] Salim HS. (2015). Tektik Pembuatan Akta Satu. Jakarta: PT. Raja Grafindo Persada.

[6] (2017). Tektik Pembuatan Akta Perjanjian (TPA DUA). Depok: PT. Raja Grafindo Persada.

[7] Urip Santoso. (2010). Pendaftaran dan Peralihan Hak atas Tanah. Jakarta: Kencana Prenadamedia Group.

Regulation:

[1] The Constitution of 1945 
[2] Civil Code (Burgerlijk Wetboek)

[3] Act No. 5 of 1960 concerning Basic Agrarian Regulations

[4] Act No. 30 of 2004 concerning Notary Position

[5] Government Regulation Number 24 of 1997 concerning Land Registration

[6] Government Regulation Number 37 of 1998 concerning Regulation of the Position of Land Deed Making Officials

[7] Presidential Regulation 10 of 2004 concerning the National Land Agency

[8] Instruction of the Minister of Home Affairs Number 14 of 1982 concerning the Prohibition of Using Absolute Power as Transfer of Rights to Land 